\title{
Türk Bankacılık Sisteminde Kamusal Sermayeli Bankaların Karşılaştırmalı Etkinlik Analizi: 2008-2017 Dönemi Değerlendirmesia
}

\author{
M. Hakan YALÇINKAYA ${ }^{\text {bc }}$, Sezen DURAMAZ ${ }^{\mathrm{d}}$
}

Özet

Kamusal sermayeli bankalar gerek ulaştıkları rakamsal büyüklükler, gerekse ülke için çok önemli projelerin hayata geçirilmesinde üstlendiği sorumluluklar bakımından hem Türk bankacılık sektörü hem de ülke için önemli roller üstlenmektedirler. Çalışma, Türk bankacılık sektöründe kamusal sermayeli bankaların etkinliklerinin karşılaştırılması amacıyla gerçekleştirilmiş olup, bu kapsamda 2008-2017 dönemleri arasında kamusal sermayeli bankaların etkinlik analizleri karşılaştırmalı olarak analiz edilmiş, yöntem olarak veri zarflama analizi kullanılmıştır. Kullanılan veriler kapsamında ele alınan yıllardaki analiz sonuçları değerlendirildiğinde Vakıfbank; Ziraatbank ve Halkbank'a göre daha etkin bir skor düzeyine sahiptir. Özellikle Vakıfbank ele alınan yılların tamamında, Ziraatbank 2008, 2016, 2017 yıllarında, Halkbank ise 2013, 2016 ve 2017 yıllarında tam etkinlik düzeyine ulaşmıştır.
Anahtar Kelimeler

Bankacilık

Veri Zarflama Analizi

Kamusal Sermayeli Bankalar

Türk Bankacıllk Sektörü

Makale Hakkında

Geliş Tarihi: 28.05.2020

Kabul Tarihi: 10.05.2021

Doi: 10.18026/cbayarsos.744169

\section{A Comparative Efficiency Analysis Of Public Capital Banks In Turkish Banking System: An Evaluation Of 2008-2017 Period}

\begin{abstract}
The public capital banks, banks play important roles for both the Turkish banking sector and the country in terms of their figures and the responsibilities they undertake in the implementation of very important projects for the country. The study was carried out in order to compare the efficiencies of public banks in Turkish banking sector, in this context, efficiency analysis of public banks between 2008-2017 was conducted comparatively by employing data envelopment analysis. After the analysis results were evaluated, Vakıfbank reached a more effective score than Ziraatbank and Halkbank. Particularly, Vakıfbank reached the full efficiency level in all of the years discussed; Ziraatbank reached full efficiency level in 2008, 2016 and 2017; Halkbank reached full efficiency level in 2013, 2016 and 2017.
\end{abstract}

\author{
Keywords \\ Banking \\ Data Envelopment Analysis \\ Public Capital Banks \\ Turkish Banking Sector \\ About Article \\ Received: 28.05.2020 \\ Accepted: 10.05 .2021
}

Doi: 10.18026/cbayarsos.744169

aBu makale, Celal Bayar Üniversitesi Sosyal Bilimler Enstitüsü'nde kabul edilen “Türk Bankacıllk Sisteminde Kamusal Sermayeli Bankaların Karşılaştırmalı Etkinlik Analizi:2008-2017 Dönemi Değerlendirmesi" konulu yüksek lisans tezinden türetilmiştir. 


\section{Giriş}

Ülke ekonomilerinin en önemli dinamiklerden olan bankalar geçmişten günümüze mevduat toplamak-kredi yaratmak gibi asli faaliyetlerini sürdürmektedirler. Her ne kadar finans piyasaları ve finansal ürünler çeşitlense, finansal alternatifler çoğalsa da ister gelişmiş, isterse gelişmekte olan ülkeler de bankalar ve bankacılık sektörü finans piyasalarının en önemli aktörü konumundadırlar.

Türk finans sistemi içerisinde bankacılık sektörünün payı yüzde 90 seviyelerindedir. Yine bu büyüklük içindeki en önemli pay mevduat bankacılığına aittir. Sistemdeki 47 bankadan 34 tanesi mevduat bankalarından meydana gelmektedir. Bu 34 bankadan Ziraat Bankası (Ziraatbank), Halk Bankası (Halkbank) ve Vakıflar Bankası (Vakıfbank) da kamusal sermaye ile Türk bankacılık sektöründe faaliyet gösteren bankalardan üç tanesidir. Geri kalan 9 banka özel sermaye, 21 banka yabancı sermaye ile faaliyetlerine devam etmektedir. Bir banka ise Tasarruf Mevduatı Sigorta Fonu altında faaliyetlerini sürdürmektedir.

Her ne kadar karlılıkları gün geçtikçe artsa da kamusal sermaye ile hizmet sunmaları çerçevesinde kamu sermayeli bankaların verimli ve etkin bir şekilde yönetilmesi gereklilik arz etmektedir. Bu kapsamda çalışmada kamusal sermayeli bankalar 2008-2017 arası dönemde karşılaştırmalı olarak "Veri Zarflama Analizi" (VZA) ile etkinlik analizine tabi tutulmuştur. Çalışmada öncelikle veri zarflama analizi tüm detaylarıyla ele alınarak devamında literatürdeki mevcut veri zarflama analizi çalışmaları derlenmiştir. Son kısımda ise araştırmanın yöntemi, kapsamı ve veri seti sunularak Türk bankacılık sisteminde kamusal sermayeye ait olan Ziraatbank, Halkbank ve Vakıfbank'ın etkinlik analizi gerçekleştirilmiştir.

\section{Kavramsal Çerçeve}

\section{Veri Zarflama Analizi (VZA)}

Veri zarflama analizi, homojen yani aynı nitelikte oldukları varsayılan ve analize dahil edilen üretim birimlerini kendi aralarında karşılaştırarak, en iyi gözlem değerini etkinlik sınırı olarak kabul eden ve geri kalan diğer gözlemleri bu en etkin gözleme göre değerlendirerek yorumlama imkan taniyan bir analizdir (İnan, 2000, s.85).

Veri zarflama analizi girdi ve çıktı odaklı yaklaşım olarak iki farklı boyutta değerlendirilebilir ve analizler de buna göre gerçekleşebilir. Bu noktada girdi odaklı uygulamada şu soruya cevap aranır: "Çıktı miktarını düşürmeden girdiler orantısal olarak ne kadar azaltılabilir?". Çıktı odaklı yaklaşımda ise şu soruya yanıt aranır: "Girdi miktarları sabitken, çıktı miktarları orantısal olarak ne kadar arttırılabilir?". İlk soru girdi odaklı, ikincisi soru ise çıktı odaklı yaklaşımı ortaya koymaktadır (Emiral, 2018).

Veri zarflama analizi ilk kez Farrell (1957) tarafından matematiksel bir kalıp eşliğinde ortaya konulmuştur. Uygulamanın hayata geçirildiği Amerikan tarım endüstrisinde yapılan çalışmada etkinlik, teknik etkinlik ve fiyat etkinliği olarak ayrı ayrı ifade edilmiş; teknik ve fiyat etkinliğinin birleşimi ise ekonomik etkinliği vermiştir. İlerleyen dönemde Charnes, Cooper ve Rhodes (1978) kamu programlarının etkinliklerinin belirlenmesinde doğrusal programlama yöntemini temel alan veri zarflama analizini geliştirmişlerdir. İlgili eserde analizler "ölçeğe göre sabit getiri" varsayımı altında gerçekleştirildiğinden literatürde analize Charnes, Cooper ve Rhodes'un yöntemi denilmiştir; yöntem isimlerinin baş harfleriyle CCR 
yöntemi olarak bilinmektedir. Ardından Banker, Charnes ve Cooper (1984), ölçek etkisinin göz ardı edilmesi konusunu ele alarak ölçeğe göre değişken getiri durumlarının esas alındığı veri zarflama analiziyle, yine isimlerinin baş harfleriyle anılan BCC yöntemiyle VZA yöntemini bir ileriki safhaya taşımıştır (Farrell, 1957; Banker vd., 1984; Gülcü vd., 2005, s.99; Kök ve Ay, 2013, s.162).

\section{Temel Veri Zarflama Analizi (VZA) Modelleri}

Veri zarflama modelleri, farklı değişkenler ve farklı durumların değerlendirilmesi çerçevesinde birkaç şekilde sinıflandırılabilmektedir. Buna göre Veri Zarflama Analizi; "ölçeğe göre sabit getiri varsayımı altında girdiye ve çıktıya yönelik olarak; kesirli, doğrusal ve zarflama modellerini içine alan CCR modelleri ve bunu takiben ölçeğe göre değişken getiri varsayımını kabul eden BCC modelleri olmak üzere" iki temel modelden meydana gelmektedir (Budak, 2011, s.98).

CCR ve BCC modelleri de kendi aralarında "girdiye yönelik" ve "çıktıya yönelik" olarak iki farklı şekilde değerlendirilebilmektedir. Genel olarak veri zarflama analizi modelleri kendi aralarında benzemekle birlikte bazı nüans farklılıkları mevcuttur. Buna göre; "girdiye yönelik VZA modelleri, belirli bir çıktı bileşimini en etkin şekilde üretebilmek amacıyla kullanılacak en uygun girdi bileşiminin nasıl olması gerektiğini araştırır. Çıktıya yönelik VZA modelleri belirli bir girdi bileşimi ile en fazla ne kadar çıktı bileşimi elde edilebileceğini araştırmaktadır" (Charnes vd., 1978 akt. Altan, 2010, s.193).

\section{Charnes, Cooper ve Rhodes-CCR Modeli}

Hem çıktıya, hem de girdiye yönelik CCR modelinde uygulanan zarflama seviyesi benzerdir. Ancak burada karar birimlerinden etkin olmayanların hem girdi, hem de çıktı odaklı CCR modelinde sınır üzerinde farklı izdüşümlerin alınması söz konusudur. Çıktıya yönelik CCR modelinde etkin olarak bulunan karar birimi girdiye yönelik modelde de etkindir. Girdiye yönelik CCR modelinin matematiksel ifadesi şöyledir (Behdioğlu ve Özcan, 2009, s.305-306):

$$
E_{k}=\operatorname{Min} \alpha-\varepsilon \sum_{i=1}^{m} s_{i}^{-}-\varepsilon \sum_{r=1}^{p} s_{r}^{+}
$$

Aşağıdaki kısıtlar altında:

$$
\begin{array}{lc}
\sum_{j=1}^{n} X_{i j} \lambda j_{j}+s_{i}^{-}-\alpha X_{i k}=0 & i=1, \ldots, m \\
\sum_{j=1}^{n} Y_{i j} \lambda_{j}-s_{r}^{+}-Y_{r k}=0 & r=1, \ldots, p \\
\lambda_{j} \geq 0 & j=1, \ldots, n ; \quad s_{i}^{-} \geq 0 \quad i=1, \ldots, m ; \quad s_{r}^{+} \geq 0 \quad r=1, \ldots, p
\end{array}
$$

“Ek: Karar biriminin etkinliği, Xij: j'nci karar birimi tarafından kullanılan i'nci girdi, Xik: k karar birimi tarafından kullanılan i'nci girdi, $Y_{i j}$ : $j$ karar birimi tarafindan üretilen i'nci çıktl, $Y_{r k:} k$ karar birimi tarafından üretilen r'nci çıktı, ع: Yeterince küçük pozitif bir sayı, n: Karar birimi sayısı, p: Çıktı sayısı, m: Girdi sayısı, $\alpha$ : Göreli etkinliği ölçülen k karar biriminin girdilerinin ne kadar azaltabileceğini belirleyen büzülme katsayısı, $s_{i}^{-}: k$ karar biriminin $i^{\prime} n c i$ girdisine ait atıl değer, $s_{r}^{+}: k$ karar biriminin

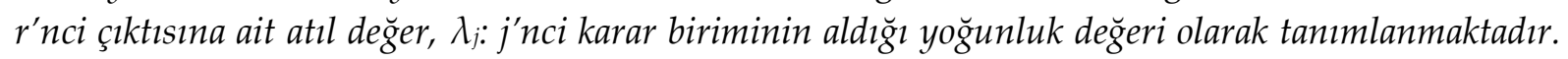
Bu modelin amaç fonksiyonunda belirli bir çıktı düzeyi için etkinliği ölçülen $k$ karar birimine ait 
girdilerin ne kadar azaltılabileceği belirlenir. Ĕğer söz konusu karar birimleri etkin ise, $\alpha=1, s_{i}=0, s_{r}{ }^{+}=0$, $\lambda_{k}=1$ ve $E_{k}=1$ olacaktır. Ĕğer ölçülen karar birimi etkin değilse etkinlik ölçütünü belirleyen $\alpha$ büzülme katsayısı 1'den küçük ve kuramsal karar birimlerin $\lambda$ 'ları 0'dan büyük olacaktır."

\section{Banker, Charnes ve Cooper Modeli-BCC Modeli}

Aynı şekilde BCC modelinde de girdiye ve çıktıya yönelik süreçlere bakıldığında; "girdiye yönelik BCC modeli, girdilerin oransal azalması boyunca, sınır doğrultusunda maksimum hareketi, çıktıya yönelik BCC modelleri ise, çıktıların oransal artırımı ile sınır doğrultusunda maksimum hareketi amaçlamaktadır". Girdiye yönelik BCC modelinin matematiksel ifadesi şöyledir (Banker vd., 1984 akt., Behdioğlu ve Özcan, 2009, s.306-307):

$$
E_{k}=\operatorname{Min} \alpha-\varepsilon \sum_{i=1}^{m} s_{i}^{-}-\varepsilon \sum_{r=1}^{r} s_{r}^{+}
$$

Aşağıdaki kısıtlar altında:

$$
\begin{array}{lc}
\sum_{j=1}^{n} X_{i j} \lambda_{j}+s_{i}^{-}-\alpha X_{i k}=0 & i=1, \ldots, m \\
\sum_{j=1}^{n} Y_{i j} \lambda_{j}-s_{r}^{+}-Y_{r k}=0 & r=1, \ldots, p \\
\sum_{j=1}^{n} \lambda_{j}=1 & \\
\lambda_{j} \geq 0 \quad j=1, \ldots, n ; \quad s_{i}^{-} \geq 0 & i=1, \ldots, m ; \quad s_{r}^{+} \geq 0 \quad r=1, \ldots, p
\end{array}
$$

“Burada; Ek: Karar biriminin etkinliği, Xij: j'nci karar birimi tarafindan kullanılan i'nci girdi, Xik: $k$ karar birimi tarafindan kullanılan i'nci girdi, $Y_{i j}$ : $j$ karar birimi tarafindan üretilen i'nci çıktl, $Y_{r k:} k$ karar birimi tarafından üretilen $r^{\prime} n c i$ çıktı, $\varepsilon$ : Yeterince küçük pozitif bir sayı, n: Karar birimi sayısı, p: Çıktı sayısı, m: Girdi sayısı, $\alpha$ : Göreli etkinliği ölçülen $k$ karar biriminin girdilerinin ne kadar azaltabileceğini belirleyen büzülme katsayısı, $s^{-}: k$ karar biriminin $i^{\prime} n c i$ girdisine ait atıl değer, $s_{r}^{+}: k$ karar biriminin $r^{\prime} n c i$ çıktısına ait atıl değer, $\lambda_{j}$ : j'nci karar biriminin aldığı yoğunluk değeri olarak tanımlanmaktadır. Bu modelin amaç fonksiyonunda belirli bir çıktı düzeyi için etkinliği ölçülen k karar birimine ait girdilerin ne kadar azaltılabileceği belirlenir. Ĕ̆ger söz konusu karar birimleri etkin ise, $\alpha$ $=1, s_{i}=0, s_{r}{ }^{+}=0, \lambda_{k}=1$ ve $E_{k}=1$ olacaktır. Eğer ölçülen karar birimi etkin değilse etkinlik ölçütünü belirleyen $\alpha$ büzülme katsayısı 1'den küçük ve kuramsal karar birimlerin $\lambda$ 'ları 0 'dan büyük olacaktır."

\section{Veri Zarflama Analizi Uygulama Aşamalan}

Farklı birçok sektörde uygulanan veri zarflama analizinin uygulama adımları şu şekildedir (Behdioğlu ve Özcan, 2009, s.303-304; Savaş, 2015, s.206-208; Tarkoçin ve Gencer, 2010, s.21-22; Babacan vd., 2009, s.25):

a. Karar Birimlerinin Seçimi: Faaliyet sürecinde benzer girdileri kullanarak yine benzer çıktılar elde edilen ve bunların karşılaştırılabilir olması mümkün olan birimler arasında veri zarflama analizi aracılığıyla etkinlik analizi yapılabilir. Ele alınan ve değerlendirilen her bir birim (ülke, banka, hastane vb.) karar verme birimi (KVB) olarak adlandırılır. Bir karar verme birimi girdileri çıktılara dönüştürerek analize imkan sağlayan herhangi bir ekonomik oluşum olabilir. Fakat burada mutlaka 
olması gereken husus; karar verme birimlerinin aynı amaç doğrultusunda aynı işleri yapması ve pazar şartları altında çalışması sürecinin gerekliliğidir. Performansı yani etkinlik değerine ulaştıracak girdi ve çıktıların aynı olurken, büyüklükleri ve yoğunlukları aynı olabilecektir.

b. Girdi ve Çıktı Seçimi: Analiz sürecinde karar verme birimleri belirlendikten sonra, girdilere ve çıtılar seçilmektedir. Girdiler ve çıtılar özenle seçilmelidir; nitekim seçilen girdi ve çıtı değişkenleri analize dahil edilen tüm karar verme birimleri için ortak özellikler taşımalıdır. Girdi çıktı sayısının çok fazla olması durumunda analizde etkin olan ve olmayan karar verme birimlerinin birbirinden ayrıştırılması zorlaşmaktadır. Bu durum ortaya çıkarsa, uzman bir kişinin görüşü alındıktan sonra aralarında korelasyon ilişkisi bulunan girdi ve çıtı verileri analize tabi tutulabilir.

c. Verilerin Elde Edilebilirliği ve Güvenirliği: Analize dahil edilecek olan verilerin güvenilir bir kaynaktan sağlanmış olması gereklidir. Doğruluğu ve kesinliği tam olarak bilinmeyen verilerle gerçekleştirilen analizin sonuçları ile karar verme birimleri hakkında sağlıklı ve sorunsuz bir yorumda bulunulamayacaktır.

d. VZA ile Göreli Etkinlik Ölçümü: Analiz hangi amaca yönelik olarak yapılıyorsa, buna uygun veri zarflama analizi modeli seçilmelidir. Veri zarflama analizi ile benzer yapıdaki karar verme birimlerinin nispi etkinlikleri ölçülür.

e. Referans Kümesi: Nispi olarak etkin olmayan karar verme birimlerinin her biri için analiz sonucunda referans kümesi şekillenir. Nispi olarak etkin karar verme birimlerinden oluşan bir ya da birden fazla karar verme birimi, göreli olarak analiz sonucunda etkin olmadığı ortaya çıkan karar verme birimi ya da birimlerinin referans kümesini oluşturur.

f. Etkin Olmayan Karar Birimleri İçin Hedef Belirlenmesi (Iyileştirme): Uygulamanın en önemli özelliklerinden bir tanesi nispi bir şekilde etkin olmadığı ortaya çıkan karar verme birimlerinin her biri için hedef rakamlar/oranlar belirlenmesidir. Referans kümesinde etkin olduğu tespit edilen karar verme birimlerinin girdileri ve çıtıları çerçevesinde etkin olmayan karar verme birimleri için potansiyel düzeltme ve iyileştirmeler belirlenir. Böylelikle karar verme birimleri etkin olmadığı noktaları görüp, referans değeri çerçevesinde etkin hale gelebilme yönünde politikalar geliştirebilirler.

g. Sonuçların Değerlendirilmesi: Analizde 1 değerine ulaşıldığında ele alınan karar verme birimleri tam etkinlik skoruna ulaşmış olur. Sonuç eğer 1 den küçük ise sonuçlar nispi olarak etkin değildir şeklinde yorumlamada bulunulabilir. Buna göre değer 0’a yaklaştıkça karar verme biriminin de etkinliği azalmaktadır.

\section{Literatür Taraması}

Bankaların ekonomide üstlendikleri önemli rolün bir göstergesi olarak Türkiye' de ve dünyada bankalara yönelik şimdiye kadar birçok model geliştirilmiş ve birçok analiz metodu 
uygulanmıştır. Bankalar faaliyet gösterdiği ülkedeki diğer bankalarla karşılaştırmalı olarak analizlerle kıyas edilmekle birlikte, aynı bankanın farklı şubeleri arasında da karşılaştırmalara tabi tutulabilmektedir. Bununla birlikte farklı yıllarda (kriz y1llarından önce/sonra) ve/veya farklı şube segmentleri (ticari şube, bireysel şube gibi) arasında da etkinlik analizi gerçekleşebilmektedir. Aynı zamanda bankalar arasındaki analizler farklı ülkelerdeki bankaların rakamlarıyla da karşılaştııılabilmektedir. Bu alanda yapılan çalışmaların bazıları şunlardır:

Taylor vd., 1989-1991 yılları arasında her bir yıl için, Meksika bankalarının Federal Hükümetin kontrolü olan yıllarda 13 Meksika bankasını sektörü veri zarflama analizi ile incelemiştir. Çalışmada Meksika bankaları etkinlik sıralamasına göre dizilmiştir. Bununla birlikte Taylor vd. karlılık ve etkinliğin farklı olduğunu belirterek, veri zarflama analizi sonucu etkin olmayan bankaların etkin olan bankalardan daha fazla karlılığının olduğun belirtmiştir (Taylor vd., 1997, s.361-362).

Tsolas ve Charles, Yunanistan'da faaliyet gösteren 14 ticaret bankasının etkinliğini veri zarflama analiziyle incelemiştir. Analiz sonucunda temel bankacılık işlemlerinin yapıldığı ve çalışmada "core-banking" grubu olarak adlandırılan 4 bankadan 3 tanesinin, diğer 10 bankadan da 7 banka etkin olarak bulunmuştur (Tsolas ve Charles, 2015, s. 3495,3498).

Repkova, 2003-2012 yıllarında Çek Cumhuriyeti'nde faaliyet gösteren ticari bankaların veri zarflama analizi yaklaşımıyla etkinliklerini incelemiştir. Sektördeki en etkin banka olarak GE Money Bank, etkinlik skoru en düşük olan banka olarak ise Cekoslovenska Obchodni Bank olarak bulunmuştur. Bununla birlikte, büyük banka gruplarının diğerlerine göre daha az etkin olduğu belirlenmiş, bunun nedeni olarak da bilançolarındaki mevduat rakamlarının yüksek olması ve uygun olmayan büyüklükteki yönetilmeleri olduğu ifade edilmiştir (Repkova, 2014, s.548).

Sufian ve Kamarudin, Bangladeş bankacılık sektöründe faaliyet gösteren 31 bankayı etkinlik açısından incelemiştir. Veri zarflama analizinin kullanıldığı etkinlik analizinde 2004-2011 yılları arasındaki veriler aracılığıyla analizler gerçekleşmiştir. İncelenen dönemde sadece 8 banka etkinliğe ulaşmıştır. Bir bankanın ekin olmasının uygun ölçekte faaliyet göstermesine bağlı olduğu yazarlar tarafından belirtilmiştir (Sufian ve Kamarudin, 2014, s.549,551).

Nguyen vd., Asya'nın gelişen ekonomilerinden biri olan Vietnam'da, bankacılık sektörünü incelemiştir. 1995 ve 2011 yılları arasında veri zarflama analiziyle etkinlikleri ölçülen bankalardan kamusal sermayeli olanlar, özel sermayeli bankalara göre daha etkin olarak saptanmıştır. Yine çalışmada, 2008'de başlayan kürsel ekonomik krizden ve Asya finansal krizinden dolayı bankaların etkinliklerinde bir değişmenin olmadığı yorumlanmıştır (Nyugen vd., 2014, s.2665).

Titko vd. 'nin çalışmasında Litvanya bankacılık sektöründe 15 bankanın, veri zarflama analiziyle etkinlik skorları gözlenmiştir. Etkinlik skorları en iyi bulunan 5 banka olarak Swedbank, ABLV Bank, Norvik Banka ve Latvijas pasta banka belirtilmiştir. Trasta Komercbanka, PrivatBank ve Regionala investiciju bankaları ise etkin olmayan bankalar olarak sayılmışlardır (Titko vd., 2014, s.746,747,754).

Wolters vd., Brezilya bankacılık sektörünü 2002-2012 yılları arasında veri zarflama analiziyle incelemiştir. Analizde Brezilya bankacıllk sektöründen en gelişmiş 50 banka seçilmiştir. Çalışma sonucunda incelenen dönem içerisinde banka büyüklüğüne ve sermaye sahibine 
bakılmaksızın bankaların etkinliğinde bir düşüş yaşandığı ifade edilmiştir (Wolters vd., 2013, s.23,31).

Zainal ve İsmail, Malezya'da faaliyet gösteren yabancı ve yerli sermayeli faizsiz bankaların 2006-2010 dönemlerini kapsayacak şekilde teknik, ölçek ve salt teknik etkinliklerini veri zarflama analiziyle incelemiştir. Analiz sonucunda Malezya'daki yerli İslami bankaların, yabancı sermayeli İslami bankalara göre teknik ve ölçek etkinliğinin yüksek olduğu belirlenmiştir. Aynı şekilde yabancı sermayeli İslami bankaların da salt teknik etkinliğinin yüksek olduğu saptanmıştır (Zainal ve İsmail, 2012, s.1).

Alam, 2006-2010 dönemlerinde 11 ülkede faaliyet gösteren 70 İslami bankanın etkinliğini veri zarflama yöntemiyle ile analiz etmiştir. Çalışmada islami bankalara yönelik sektördeki denetim, düzenleme ve gözlemlerin bankaların etkinliğini artırıp arttırmadığının saptanması amaçlanmıştır. Analiz ve değerlendirmeler sonucunda da İslami bankalar üzerindeki gözetim ve denetimin bankalar üzerindeki teknik etkinliği arttırdığı sonucuna ulaşılmıştır (Alam, 2013, s.29,43).

Sufian, Malezya İslami bankacılık sektörünü 2001-2005 döneminde incelemiştir. Uygulanan veri zarflama analizi sonucunda yabancı sermayeli İslami bankalar, yerli sermayeli bankalara göre teknik olarak daha etkin bulunmuştur (Sufian, 2007, s.53).

Johnes vd., 2004-2009 arası dönemde nüfusunun en az yüzde 60'1 Müslüman olan 18 ülkede faaliyet gösteren 207' si konvansiyonel, 45'i İslami olmak üzere toplam 252 bankanın etkinliğini veri zarflama analiziyle incelemiştir. Konvansiyonel ve İslami bankaların etkinliklerinin veri zarflama analiziyle karşılaştırılması sonucu her iki tür banka tipinin toplam etkinliklerinde belirgin bir fark gözlemlenmemiştir (Johnes vd, 2014, s.98-104).

Bader vd., 43 İslami ve 37 konvansiyonel bankayı veri zarflama analiziyle incelemiştir. 19902005 dönemlerini kapsayan çalışmada veriler 21 farklı ülkede faaliyet gösteren bankalardan elde edilmiştir. Etkinliklerinin banka büyüklükleri, kuruluş yılları faaliyet gösterdikleri bölgelere göre değerlendirildiği analiz sonucunda, İslami ve konvansiyonel bankaların etkinlikleri arasında önemli bir fark gözlemlenmemiştir (Bader vd., 2008, s.23).

\section{Araştırmanın Yöntemi, Kapsamı ve Veri Seti}

Türkiye'de, bankacılık uygulamaları Osmanlı Devleti döneminde başlamış ve Türkiye Cumhuriyetinin ilanından sonra İzmir İktisat Kongresi'nde alınan kararlar ile kamu ve özel bankacilık sektörü gelişmeye başlamıştır. Tüm dünyada olduğu gibi Türkiye de de finansal piyasalara yön ve yol verme açısından bankalar ve bankacılık sektörü çok önemli bir paya sahiptir. Bankalar ekonomide tasarruf-yatırım arasındaki dengenin sağlanması dışında ekonomiye düzenli fon akışını sağlamak, kaydi para yaratmak ülkede uygulanan para-maliye politikalarını yürütülmesine yardımcı olmak gibi ekonomik açıdan birçok önemli alanda faaliyetlere sahiptirler.

Türkiye'de kamu sermayeli bankalar dönemi 1933 yılında başlamıştır. İlk olarak Sümerbank ve İller Bankası, 1935 yılında Etibank, 1937 yılında Denizbank kurulmuştur. Bu yıllarda izlenen ekonomi ve sanayi politikaları çerçevesinde milli gelirde ki artış, şehir nüfusunun artmaya başlaması, sanayileşme hamleleri, üretimin genişlemesi, para ve kredi hacmindeki büyüme yeni bankacılık faaliyetlerinin de artmasına yol açmıştır. Garanti Bankası (1946), Akbank (1948), Pamukbank (1955) ve Türkiye Sınai Kalkınma Bankası (1950) bu dönemde kurulup faaliyetlerine başlamışlardır (Yetiz,2016, s.111). 
Günümüz itibariyle ülkemizde faaliyetlerine devam eden kamusal sermayeli bankalardan en büyük ölçekli olanları Türkiye Cumhuriyeti Ziraat Bankası A.Ş. (Ziraatbank), Türkiye Halk Bankası A.Ş. (Halkbank), Türkiye Vakıflar Bankası T.A.O. (Vakıfbank), özel sermayeli bankalar ise Adabank A.Ş., Akbank T.A.Ş., Anadolubank A.Ş., Fibabanka A.Ş., Şekerbank T.A.Ş., Turkish Bank A.Ş., Türk Ekonomi Bankası A.Ş., Türkiye İş Bankası A.Ş., Yapı ve Kredi Bankası A.Ş.'dir.

Bu bankalardan Türkiye de sermayesi devlete ait olan kamusal sermayeli bankalar arasında en çok bilineni ve sermaye büyüklüğü açısından çok önemli bir paya sahip olan bankalar arasında birinci sırada Ziraatbank, ikinci sırada Halkbank ve ardından Vakıfbank gelmektedir. Ziraat bankası; devlet teşvikli çiftçi ve hayvan kredisi imkanları ile tarım ve hayvancılığ destekleyen ve bu amaçla krediler veren bir kamu bankasıdır. Halkbank; KOBİ ve esnafları desteklemek amacı ile devlet tarafından hibe veya faizsiz kredi sunan bir bankadır. Ayrıca TOKİ ve devlete ait gayrimenkul satışları da bu banka aracılığı ile gerçekleştirilir. Vakıfbank ise; gene devlete ait olan bir bankadır. Vakıfbank da diğer kamu sermayeli bankalar gibi ticari, KOBİ ve tarımsal işletmelere yönelik bankacılığının yanı sıra bireysel ve özel bankacılık alanlarında da finansal ürün ve hizmetleri sunan birçok finansal alanda uzmanlaşmış bir bankadir.

Tablo 1. Kamusal Sermayeli Bankalar (Milyon TL)

\begin{tabular}{lccc}
\hline & $\begin{array}{c}\text { Toplam } \\
\text { Özkaynaklar }\end{array}$ & $\begin{array}{c}\text { Ödenmiş } \\
\text { Sermaye }\end{array}$ & $\begin{array}{c}\text { Net Dönem } \\
\text { Kar/Zararı }\end{array}$ \\
\hline T.C. Ziraat Bankası A.Ş. & 70064,54 & 6100 & 6186,888 \\
Türkiye Halk Bankası A.Ş. & 32196,83 & 1250 & 1720,309 \\
Türkiye Vakıflar Bankası T.A.O. & 33026,27 & 2500 & 2802,291 \\
\hline
\end{tabular}

Kaynak: TBB

Bu nedenle çalışmada karar verme birimi olarak ülke ekonomisinde önemli bir yere sahip olan üç kamu bankası ve girdi - çıktı olarak ise toplamda 5 değişken seçilmiş ve analiz gerçekleştirilmiştir. Nitekim Türk bankacılık sektöründeki en fazla toplam kamusal sermayeli mevduat bankası sayısı da toplam da üç (Ziraatbank, Halkbank, Vakıfbank) olduğu için burada karar verme birimlerinin arttırılamaması çalışmanın kısıtıdır.

Bununla birlikte karar verme birimleri ile seçilen girdi-çıktıya ilişkin kıyaslama çerçevesinde literatürdeki bazı çalışmalarda incelenmiş ve bu kısıt durumu zorunluluğu çerçevesinde gerçekleştirilen çalışmalarda araştırmamızı destekler niteliktedir. Örneğin Ayrıçay ve Özçalıcı (2015) tarafından sunulan literatür araştırması tablosu kapsamında Kutlar ve Kartal (2004) çalışmasında 8 Karar verme birimi ile 7 girdi-4 çıtı olmak üzere 11 değişken kullanmış, Özgür (2008) 5 karar verme birimi ile 5 girdi-2 çıktı olmak üzere 7 değişken kullanmış, Temür (2009) 12 karar verme birimi ile 4 girdi-8 çıtı olmak üzere 12 değişken kullanmış, Kaygısız ve Girginer (2011) 16 karar verme birimi ile 11 girdi-8 çıtı olmak üzere 19 değişken kullanmıştır.

Yukarıdaki çalışmalarda da olduğu gibi Türk bankacılık sektöründe faaliyet gösteren Ziraatbank, Halkbank ve Vakıfbank olmak üzere 3 adet kamu sermayeli mevduat bankasının 2008-2017 yılına ait verilerinden 3 tanesi girdi ve 2 adet kalemi de çıktı olarak kullanılarak veri zarflama analizi gerçekleştirilmiştir. Bankalara ait olan ve analizde kullanılan verilere Türkiye Bankalar Birliği'nin internet sitesi (www.tbb.org.tr) üzerinden ulaşılmıştır. İncelenen bankaların girdi ve çıtı değerleri yıllık olarak hesaplanmıştır. 
Kamusal sermayeli bankaların ulaştıkları rakamsal büyüklükler, Türk bankacılık sistemi içindeki yüksek payları, ülke için büyük projelerin hayata geçirilmesinde üstlendiği sorumluluklar gibi nedenler çerçevesinde örneklem olarak seçilen kamusal sermayeli bankaların kriz sonrası dönemde etkinliklerinin ölçülmesi kapsamında 2008 krizi sonrası dönemin değerlendirilmesi çerçevesinde 2017 yılına kadar olan zaman dilimi analiz edilmiş, kamusal sermayeli bankaların etkinliğinin ölçümünde kullanılan veri zarflama analizinin gerek duyduğu girdiler ve çıtılar Tablo 2' de verilmiştir.

Tablo 2. Veri Zarflama Analizinde Kullanılan Girdi ve Çıktılar

\begin{tabular}{c|c}
\hline GÍRDİLER & ÇIKTILAR \\
\hline $\mathrm{X}_{1}:$ Çalışan Sayısı & $\mathrm{Y}_{1}:$ Krediler ve Alacaklar \\
$\mathrm{X}_{2}$ : Şube Sayısı & $\mathrm{Y}_{2}:$ Aktif \\
$\mathrm{X}_{3}$ : Mevduat & \\
\hline
\end{tabular}

Buna göre kamusal sermayeli bankaların etkinlik analizinde kullanılacak 3 adet girdi kalemi ve 2 adet çıktı kalemi bulunmaktadır. Girdi kalemleri; çalışan sayısı, şube sayısı ve mevduat kalemleriyken, çıktı kalemleri; kredi ve alacaklar ile aktif" kalemidir. Ziraatbank, Halkbank ve Vakıfbank'a ait girdi göstergeleri Tablo 3' de oluşturulmuştur.

Tablo 3. Seçilen Banka Örneklerinde Gerçekleşen Girdi Göstergeleri

\begin{tabular}{|c|c|c|c|c|}
\hline & & Ziraatbank & Halkbank & Vakıfbank \\
\hline \multirow{3}{*}{2008} & Çalışan sayısı & 21.299 & 12.467 & 9.567 \\
\hline & Şube Sayısı & 1.269 & 622 & 525 \\
\hline & Mevduat & 83.883 .435 & 40.271.114 & 44.651 .723 \\
\hline \multirow{3}{*}{2009} & Çalışan sayısı & 22.198 & 12.505 & 10.153 \\
\hline & Şube Sayısı & 1.316 & 669 & 545 \\
\hline & Mevduat & 98.529 .467 & 43.949 .703 & 44.651 .723 \\
\hline \multirow{3}{*}{2010} & Çalışan sayısı & 22.708 & 13.450 & 11.077 \\
\hline & Şube Sayısı & 1.399 & 709 & 636 \\
\hline & Mevduat & 125.796 .472 & 54.782 .014 & 47.701.275 \\
\hline \multirow{3}{*}{2011} & Çalışan sayısı & 24.374 & 13.643 & 12.222 \\
\hline & Şube Sayısı & 1.458 & 771 & 680 \\
\hline & Mevduat & 113.066 .682 & 66.246 .934 & 60.939 .218 \\
\hline \multirow{3}{*}{2012} & Çalışan sayısı & 23.153 & 14.971 & 13.463 \\
\hline & Şube Sayısı & 1.514 & 821 & 744 \\
\hline & Mevduat & 118.966.304 & 79.973 .901 & 67.242 .290 \\
\hline \multirow{3}{*}{2013} & Çalışan sayısı & 24.725 & 14.798 & 14.943 \\
\hline & Şube Sayısı & 1.661 & 877 & 859 \\
\hline & Mevduat & 141.735 .146 & 100.756 .197 & 81.532 .814 \\
\hline \multirow{3}{*}{2014} & Çalışan sayısı & 23.617 & 17.314 & 14.920 \\
\hline & Şube Sayısı & 1.707 & 900 & 893 \\
\hline & Mevduat & 153.255.248 & 103.708 .354 & 91.756 .968 \\
\hline \multirow{3}{*}{2015} & Çalışan sayısı & 25.697 & 17.104 & 15.410 \\
\hline & Şube Sayısı & 1.812 & 949 & 920 \\
\hline & Mevduat & 186.469 .435 & 122.145 .965 & 109.922 .534 \\
\hline \multirow{3}{*}{2016} & Çalışan sayısı & 25.015 & 16.956 & 15.615 \\
\hline & Şube Sayısı & 1.814 & 964 & 924 \\
\hline & Mevduat & 223.018 .934 & 150.262 .839 & 123.838 .377 \\
\hline \multirow{2}{*}{2017} & Çalışan sayısı & 24.554 & 17.851 & 16.097 \\
\hline & Şube Sayısı & 1.781 & 969 & 927 \\
\hline
\end{tabular}


Türk Bankacılık Sisteminde Kamusal Sermayeli Bankaların Karşılaştırmalı Etkinlik Analizi: 2008-2017 Dönemi Değerlendirmesi

\begin{tabular}{c|c|c|c}
\hline & Ziraatbank & Halkbank & Vakıfbank \\
\hline Mevduat & 266.384 .189 & 193.227 .069 & 155.277 .122 \\
\hline
\end{tabular}

Kaynak: Türkiye Bankalar Birliği

Ziraatbank, Halkbank ve Vakıfbank'a ait çıktı göstergeleri Tablo 4' de oluşturulmuştur.

Tablo 4. Seçilen Banka Örneklerinde Gerçekleşen Çıktı Göstergeleri

\begin{tabular}{ccccc}
\hline \multirow{2}{*}{2008} & & Ziraatbank & Halkbank & Vak1fbank \\
\hline \multirow{2}{*}{2009} & Kredi ve Alacaklar & 30.836 .134 & 25.836 .298 & 30.502 .299 \\
& Aktif & 104.412 .496 & 51.095 .895 & 52.193 .493 \\
\hline \multirow{2}{*}{2010} & Kredi ve Alacaklar & 36.724 .567 & 32.458 .071 & 34.572 .655 \\
& Aktif & 124.528 .532 & 60.650 .086 & 64.797 .642 \\
\hline \multirow{2}{*}{2011} & Kredi ve Alacaklar & 57.443 .453 & 44.296 .487 & 44.861 .019 \\
& Aktif & 151.159 .708 & 72.492 .385 & 73.961 .687 \\
\hline \multirow{2}{*}{2012} & Aktif & 71.429 .975 & 56.216 .404 & 57.309 .232 \\
& Kredi ve Alacaklar & 71.426 .479 & 91.123 .660 & 89.184 .466 \\
\hline \multirow{2}{*}{2013} & Aktif & 162.867 .757 & 65.893 .838 & 68.133 .039 \\
& Kredi ve Alacaklar & 111.047 .973 & 108.281 .636 & 104.580 .263 \\
\hline \multirow{2}{*}{2014} & Aktif & 207.529 .954 & 84.848 .290 & 86.752 .217 \\
& Kredi ve Alacaklar & 141.914 .662 & 139.943 .507 & 135.496 .043 \\
\hline \multirow{2}{*}{2015} & Aktif & 247.600 .311 & 101.766 .924 & 104.583 .517 \\
& Kredi ve Alacaklar & 186.812 .851 & 155.423 .019 & 158.217 .726 \\
\hline \multirow{2}{*}{2016} & Aktif & 302.848 .326 & 126.744 .977 & 123.780 .653 \\
& Kredi ve Alacaklar & 232.643 .535 & 187.729 .350 & 182.947 .124 \\
\hline \multirow{2}{*}{2017} & Aktif & 357.761 .365 & 158.354 .333 & 147.712 .375 \\
& Kredi ve Alacaklar & 295.258 .032 & 231.440 .818 & 212.539 .905 \\
\hline \multirow{2}{*}{20} & Aktif & 203.464 .477 & 183.971 .615 \\
\hline
\end{tabular}

Kaynak: Türkiye Bankalar Birliği.

\section{Uygulama}

Etkinlik ölçümünün gerçekleştirilmesinde ise VZA etkinlik ölçümlerinde başvurulan DEAP 2.1 programından faydalanılmıştır.

Seçilen banka örnekleri kapsamında, üç girdi-iki çıtı belirlendikten sonra CCR modelinde girdi yönelimli VZA yöntemine göre etkinlik analizi gerçekleştirilmiştir.

Bankaların 2008-2017 yıllarını içeren dönem itibariyle elde ettikleri etkinlik skorları Tablo 5'de verilmiştir.

Tablo 5. Veri Zarflama Analizine Göre (VZA) Kamusal Sermayeli Bankaların Etkinlik Düzeyleri (2008-2017)

\begin{tabular}{cccc}
\hline Y11/Karar Verme Birimi & Ziraatbank & Halkbank & Vakıfbank \\
\hline 2008 & 1.000 & 0,902 & 1.000 \\
2009 & 0,879 & 0,954 & 1.000 \\
2010 & 0,997 & 0,886 & 1.000 \\
2011 & 0,971 & 0,940 & 1.000 \\
2012 & 0,906 & 0,938 & 1.000 \\
2013 & 0,918 & 1.000 & 1.000
\end{tabular}




$\begin{array}{llll}2014 & 0,989 & 0,975 & 1.000 \\ 2015 & 0,993 & 0,995 & 1.000 \\ 2016 & 1.000 & 1.000 & 1.000 \\ 2017 & 1.000 & 1.000 & 1.000\end{array}$

Buna göre girdilerin ve çıktıların ağırlıklandırılmasına göre en az girdi ile en fazla çıktı sağlayan ve tam etkin olan banka Vakıfbank'tır. Vakıfbank, Ziraatbank ve Halkbank'a göre genel olarak yıl bazında kullanılan girdi ve çıktılar kapsamında daha etkin bir skora ulaşmıştır. Bununla birlikte Ziraatbank ve Halkbank'ın da 2008-2017 dönemi içinde kullanılan veriler kapsamında etkin olduğu bazı yıllar söz konusudur. 2008 ve 2016 yıllarında Ziraatbank bu çerçevede en az girdi ile en fazla çıktıya ulaşmış ve tam etkinlik skoru olan 1'e ulaşmıştır. Yine Halkbank da 2013 ve 2016 yıllarında bu çerçevede en az girdi ile en fazla çıtıya ulaşmış, tam etkinlik skoru olan 1'i yakalamıştır.

Yıllara göre Ziraatbank, Halkbank ve Vakıfbank'ın etkinlik skorları Grafik 1'de verilmiştir.

\section{Grafik 1. Veri Zarflama Analizine (VZA) Göre Kamusal Sermayeli Bankaların Etkinlik Düzeyleri (2008-2017)}

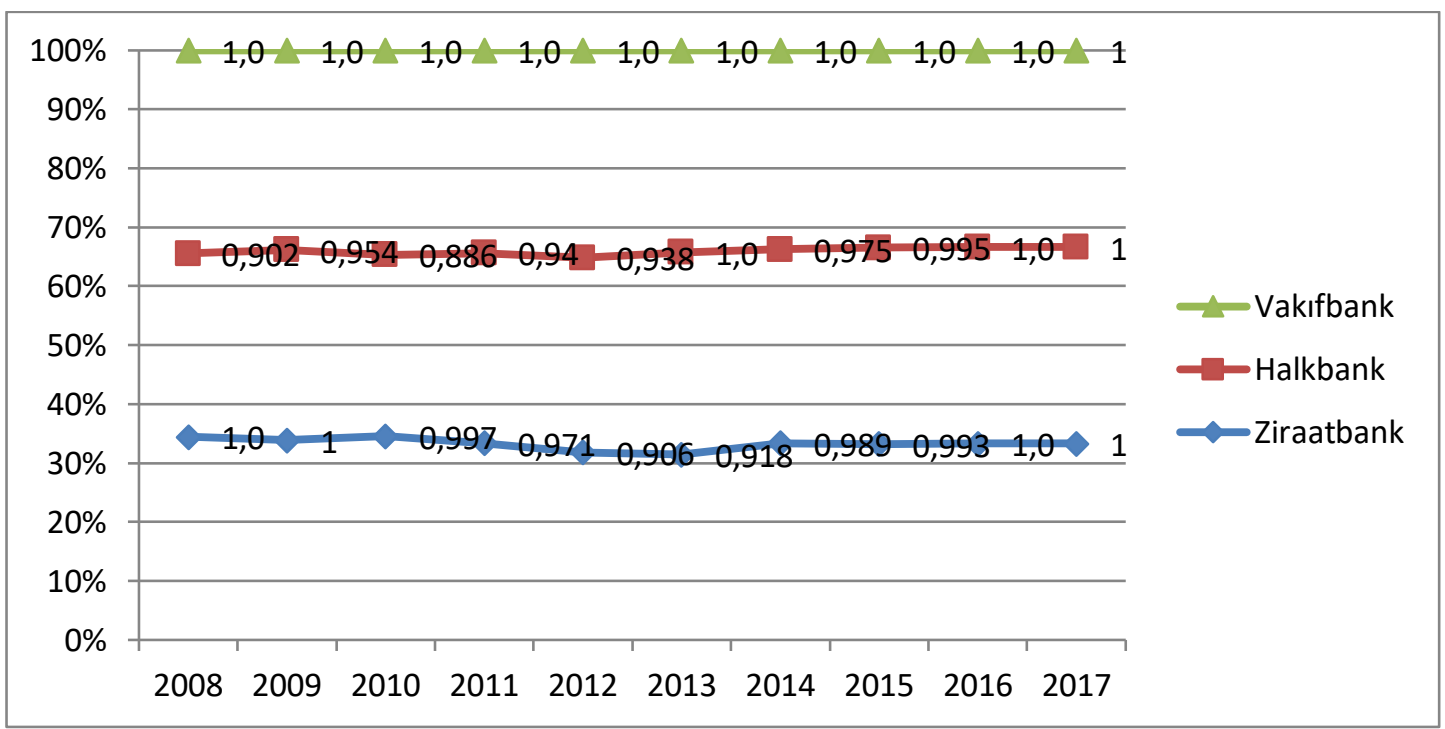

Grafik 1'den görüleceği üzere Vakıfbank'ın etkinlik düzeyi ele alınan tüm yıllarda tam etkinlik düzeyindedir ve Vakıfbank böylelikle diğer bankalar için referans alınacak banka konumundadır. Grafik aynı zamanda diğer bankaların etkin banka olan Vakıfbank'ın etkinlik düzeyine olan uzaklığını da ortaya koymaktadır.

Veri zarflama analizi incelemeye alınan tüm karar verme birimleri içindeki en etkin karar verme birimini belirlemeye yöneliktir. En etkin karar verme birimi pareto optimal birim olarak isimlendirilir ve diğer birimlerle kıyas edilme noktasında standart birim (referans alınan birim) olarak düşünülür (Gülcü vd., 2005, s.190-201). Dolayısıyla ele alınan bankalar arasında göreceli olarak en etkin banka Vakıfbank'tır ve diğer bankaların etkinlikleri analiz çıktıları kapsamında Vakıfbank'a göre değerlendirilmektedir. 
Bankaların ayrı ayrı etkinlik düzeylerinin incelenmesi ve etkin olan sınıra ulaşabilmesi kapsamında referans alması gerekli hedef rakamları ve oranları gösteren değerler Tablo 6, Tablo 7 ve Tablo 8 eşliğinde verilmiştir.

Vakıfbank'ın 2008-2017 dönemindeki etkinlik göstergeleri Tablo 6'da verilmiştir.

Tablo 6. Vakıfbank VZA Sonuçları

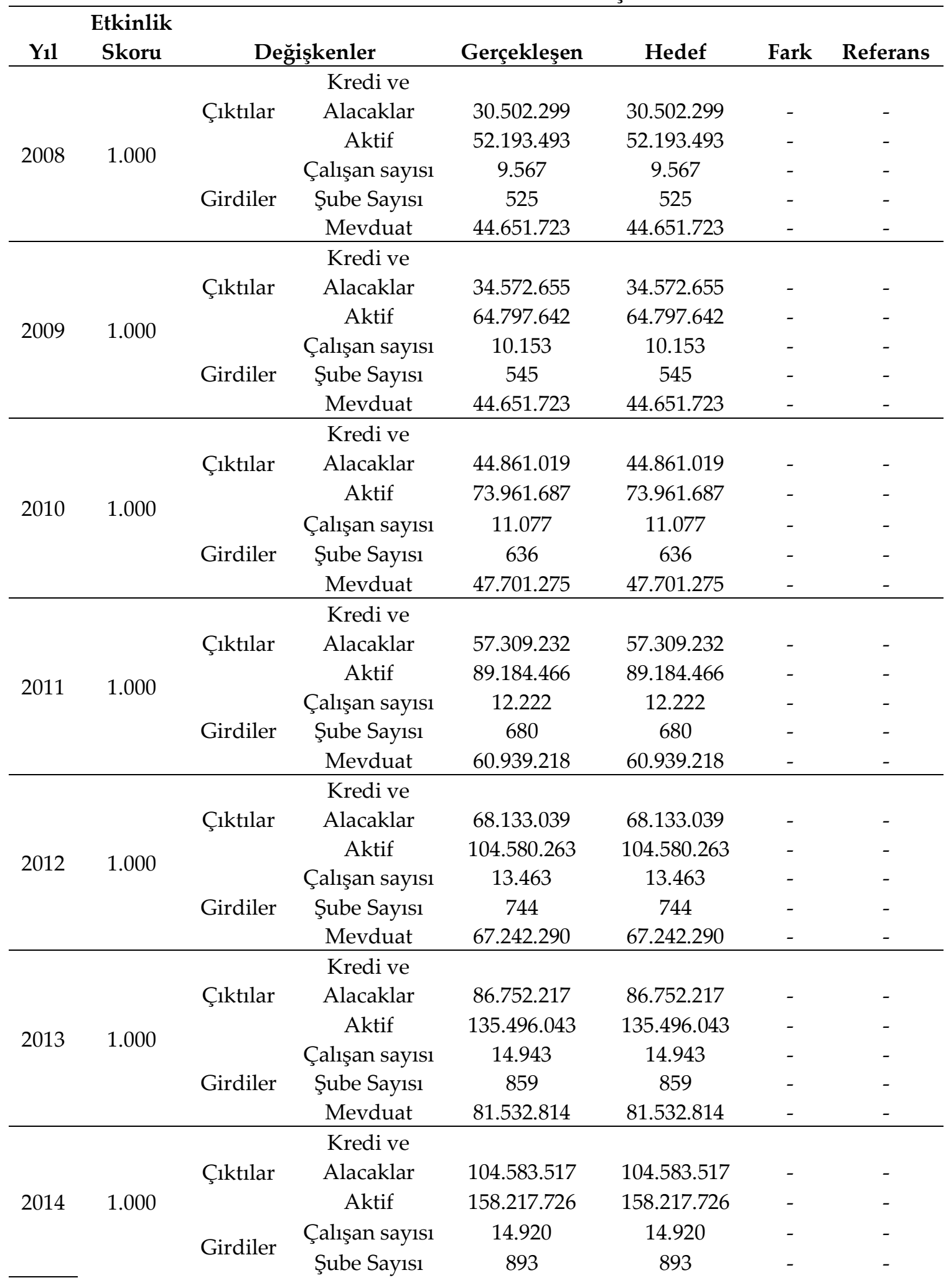




\begin{tabular}{|c|c|c|c|c|c|c|c|}
\hline & & & Mevduat & 91.756 .968 & 91.756 .968 & - & - \\
\hline \multirow{6}{*}{2015} & \multirow{6}{*}{1.000} & \multirow{4}{*}{ Çıktılar } & Kredi ve & & & & \\
\hline & & & Alacaklar & 123.780 .653 & 123.780 .653 & - & - \\
\hline & & & Aktif & 182.947.124 & 182.947.124 & - & - \\
\hline & & & Çalışan sayısı & 15.410 & 15.410 & - & - \\
\hline & & \multirow[t]{2}{*}{ Girdiler } & Şube Sayısı & 920 & 920 & - & - \\
\hline & & & Mevduat & 109.922 .534 & 109.922 .534 & - & - \\
\hline \multirow{6}{*}{2016} & \multirow{6}{*}{1.000} & \multirow{4}{*}{ Çıktılar } & Kredi ve & & & & \\
\hline & & & Alacaklar & 147.712.375 & 147.712.375 & - & - \\
\hline & & & Aktif & 212.539 .905 & 212.539 .905 & - & - \\
\hline & & & Çalışan sayısı & 15.615 & 15.615 & - & - \\
\hline & & \multirow[t]{2}{*}{ Girdiler } & Şube Sayısı & 924 & 924 & - & - \\
\hline & & & Mevduat & 123.838 .377 & 123.838 .377 & - & - \\
\hline \multirow{5}{*}{2017} & \multirow{5}{*}{1.000} & \multirow[t]{3}{*}{ Çıktılar } & $\begin{array}{l}\text { Kredi ve } \\
\text { Alacaklar }\end{array}$ & 183.971 .615 & 183.971 .615 & - & - \\
\hline & & & Aktif & 270.571 .510 & 270.571 .510 & - & - \\
\hline & & & Çalışan sayısı & 16.097 & 16.097 & - & - \\
\hline & & \multirow[t]{2}{*}{ Girdiler } & Şube Sayısı & 927 & 927 & - & - \\
\hline & & & Mevduat & 155.277 .122 & 155.277 .122 & - & - \\
\hline
\end{tabular}

Tablo 6 incelendiğinde 2008-2017 yılı için Vakıfbank, analizde kullanılan girdi ve çıktılarla tam etkinlik düzeyi olan 1'e ulaşmıştır. Tam etkinlik düzeyine ulaşan Vakıfbank'ın girdi ve çktı düzeylerinde herhangi bir değişiklik yapılması söz konusu değildir.

Ziraatbank'ın 2008-2017 dönemindeki etkinlik göstergeleri Tablo 7'de yer almaktadır. Ziraatbank 2008, 2016 ve 2017 yıllarında kullanılan girdi ve çıktıların analizi sonrasında tam etkinlik skoru olan 1'e ulaşmıştır.

Tablo 7. Ziraatbank VZA Sonuçları

\begin{tabular}{|c|c|c|c|c|c|c|c|}
\hline Y1l & Etkinlik Skoru & & Değişkenler & Gerçekleşen & Hedef & Fark & Referans \\
\hline \multirow{5}{*}{2008} & \multirow{5}{*}{1.000} & \multirow{2}{*}{ Çıktılar } & Kredi ve Alacaklar & 30.836 .194 & 30.836 .194 & - & - \\
\hline & & & Aktif & 104.412 .496 & 104.412 .496 & - & - \\
\hline & & \multirow{3}{*}{ Girdiler } & Çalışan sayısı & 21.299 & 21.299 & - & - \\
\hline & & & Şube Sayısı & 1.269 & 1.269 & - & - \\
\hline & & & Mevduat & 83.883 .435 & 83.883 .435 & - & - \\
\hline \multirow{5}{*}{2009} & \multirow{5}{*}{0,879} & \multirow{2}{*}{ Çıktılar } & Kredi ve Alacaklar & 36.724 .567 & 66.441 .954 & 29.717 .387 & Vakıfbank \\
\hline & & & Aktif & 124.528 .532 & 124.528 .532 & - & - \\
\hline & & \multirow{3}{*}{ Girdiler } & Çalışan sayısı & 22.198 & 19.512 & -2.686 & Vakıfbank \\
\hline & & & Şube Sayısı & 1.316 & 1.047 & -269 & Vakıfbank \\
\hline & & & Mevduat & 98.529 .467 & 85.811 .973 & -12.717 .494 & Vakıfbank \\
\hline \multirow{5}{*}{2010} & \multirow{5}{*}{0,997} & \multirow{2}{*}{ Çıktılar } & Kredi ve Alacaklar & 57.443 .453 & 91.685 .017 & 34.241 .564 & Vakıfbank \\
\hline & & & Aktif & 151.159.708 & 151.159.708 & - & - \\
\hline & & \multirow{3}{*}{ Girdiler } & Çalışan sayısı & 22.708 & 22.639 & -69 & Vakıfbank \\
\hline & & & Şube Sayısı & 1.399 & 1299 & -100 & Vakıfbank \\
\hline & & & Mevduat & 125.796 .472 & 97.849 .809 & -27.946 .663 & Vakıfbank \\
\hline \multirow{5}{*}{2011} & & \multirow{2}{*}{ Çıktılar } & Kredi ve Alacaklar & 71.429 .975 & 103.252 .430 & 31.822 .455 & Vakıfbank \\
\hline & & & Aktif & 160.681 .142 & 160.681 .142 & - & - \\
\hline & 0,971 & \multirow{3}{*}{ Girdiler } & Çalışan sayısı & 24.374 & 22.020 & -2.354 & Vakıfbank \\
\hline & & & Şube Sayısı & 1.458 & 1.225 & -233 & Vakıfbank \\
\hline & & & Mevduat & 113.066 .682 & 109.792 .472 & -3.274 .210 & Vakıfbank \\
\hline \multirow{2}{*}{2012} & \multirow{2}{*}{0,906} & \multirow{2}{*}{ Çıktılar } & Kredi ve Alacaklar & 71.426 .479 & 106.106 .782 & 34.680 .303 & Vakıfbank \\
\hline & & & Aktif & 162.867 .757 & 162.867 .757 & - & - \\
\hline
\end{tabular}


Türk Bankacılık Sisteminde Kamusal Sermayeli Bankaların Karşılaştırmalı Etkinlik Analizi: 2008-2017 Dönemi Değerlendirmesi

\begin{tabular}{|c|c|c|c|c|c|c|c|}
\hline Yil & Etkinlik Skoru & & Değişkenler & Gerçekleşen & Hedef & Fark & Referans \\
\hline & & & Çalışan sayısı & 23.153 & 20.966 & -2.187 & Vakıfbank \\
\hline & & Girdiler & Şube Sayısı & 1.514 & 1.158 & -356 & Vakıfbank \\
\hline & & & Mevduat & 118.966 .304 & 104.719 .577 & -14.786 .727 & Vakıfbank \\
\hline \multirow{5}{*}{2013} & \multirow{5}{*}{0,918} & \multirow{2}{*}{ Çıktılar } & Kredi ve Alacaklar & 111.047 .973 & 131.384 .689 & 20.336 .716 & Vakıfbank \\
\hline & & & Aktif & 207.529 .954 & 207.529 .954 & - & - \\
\hline & & \multirow{3}{*}{ Girdiler } & Çalışan sayısı & 24.725 & 22.688 & -2.037 & Vakıfbank \\
\hline & & & Şube Sayısı & 1.661 & 1.312 & -349 & Vakıfbank \\
\hline & & & Mevduat & 141.735 .146 & 130.059 .210 & -11.675 .936 & Vakıfbank \\
\hline \multirow{5}{*}{2014} & \multirow{5}{*}{0,989} & \multirow{2}{*}{ Çıktılar } & Kredi ve Alacaklar & 141.914 .662 & 163.666 .309 & 21.751 .647 & Vakıfbank \\
\hline & & & Aktif & 247.600 .311 & 247.600 .311 & - & - \\
\hline & & \multirow{3}{*}{ Girdiler } & Çalışan sayısı & 23.617 & 23.348 & -268 & Vakıfbank \\
\hline & & & Şube Sayısı & 1.707 & 1.397 & -310 & Vakıfbank \\
\hline & & & Mevduat & 153.255.248 & 143.593 .606 & -9.661 .642 & Vakıfbank \\
\hline \multirow{5}{*}{2015} & \multirow{5}{*}{0,993} & \multirow{2}{*}{ Çıktılar } & Kredi ve Alacaklar & 186.812 .851 & 204.904 .907 & 18.092 .056 & Vakıfbank \\
\hline & & & Aktif & 302.848 .326 & 302.848 .326 & - & - \\
\hline & & \multirow{3}{*}{ Girdiler } & Çalışan sayısı & 25.697 & 25.509 & -187 & Vakıfbank \\
\hline & & & Şube Sayısı & 1.812 & 1.522 & -290 & Vakıfbank \\
\hline & & & Mevduat & 186.469 .435 & 181.964 .354 & -4.505 .081 & Vakıfbank \\
\hline \multirow{5}{*}{2016} & \multirow{5}{*}{1.000} & \multirow{2}{*}{ Çıktılar } & Kredi ve Alacaklar & 232.643 .535 & 232.643 .535 & - & - \\
\hline & & & Aktif & 357.761 .365 & 357.761 .365 & - & - \\
\hline & & \multirow{3}{*}{ Girdiler } & Çalışan sayısı & 25.015 & 25.015 & - & - \\
\hline & & & Şube Sayısı & 1.814 & 1.814 & - & - \\
\hline & & & Mevduat & 223.018 .934 & 223.018 .934 & - & - \\
\hline \multirow{5}{*}{2017} & & \multirow{2}{*}{ Çıktılar } & Kredi ve Alacaklar & 295.258 .032 & 295.258 .032 & - & - \\
\hline & & & Aktif & 434.274 .509 & 434.274 .509 & - & - \\
\hline & 1.000 & \multirow{3}{*}{ Girdiler } & Çalışan sayısı & 24.554 & 24.554 & - & - \\
\hline & & & Şube Sayısı & 1.781 & 1.781 & - & - \\
\hline & & & Mevduat & 266.384.189 & 266.384.189 & - & - \\
\hline
\end{tabular}

Ziraatbank'ın veri zarflama analizi sonuçlarına göre etkin olmadığı dönemlerde etkinlik sınırına doğru yönelerek tam etkin olabilmesi için girdi ve çıtı kalemlerine yönelik yapması gerekli iyileştirmeler yıllar bazında aşağıda verilmiştir:

a. 2008 yılı için Ziraatbank tam etkinlik düzeyi olan 1'e ulaştığı için girdi ve çıtı düzeylerinde herhangi bir değişiklik yapılmamalıdır.

b. 2009 yılı için Aktif çıktısı değişmemelidir. Kredi ve alacaklar çıktısı 29.717.387 bin TL arttırılmalıdır. Girdiler açısından bakıldığında ise çalışan sayısı 269, şube sayısı 2.686 ve mevduat kalemi 12.717.494 bin TL azaltılmalıdır.

c. 2010 yılı için aktif çıtısı değişmemelidir. Kredi ve alacaklar çıtısı 34.241 .564 bin TL arttırılmalıdır. Girdiler açısından bakıldığında çalışan sayısı 69, şube sayısı 100 ve mevduat kalemi 27.946.663 bin TL azaltılmalıdır.

d. 2011 yılı için aktif çıtısı değişmemelidir. Kredi ve alacaklar çıtısı 31.822.455 bin TL arttırılmalıdır. Girdiler açısından bakıldığında çalışan sayısı 2.354, şube sayısı 233 ve mevduat kalemi 3.274.210 bin TL azaltılmalıdır. 
e. 2012 yılı için aktif çıtısı değişmemelidir. Kredi ve alacaklar çıtısı 34.680.303 bin TL arttırılmalıdır. Girdiler açısından bakıldığında çalışan sayısı 2.187, şube sayısı 356 ve mevduat kalemi 14.786.727 bin TL azaltılmalıdır.

f. 2013 yılı için aktif çıtısı değişmemelidir. Kredi ve alacaklar çıktısı 20.336.716 bin TL arttırılmalıdır. Girdiler açısından bakıldığında çalışan sayısı 2.037, şube sayısı 349 ve mevduat kalemi 11.675.936 bin TL azaltılmalıdır.

g. 2014 yılı için aktif çıtısı değişmemelidir. Kredi ve alacaklar çıtısı 21.751.647 bin TL arttırılmalıdır. Girdiler açısından bakıldığında çalışan sayısı 268, şube sayısı 310 ve mevduat kalemi 9.661.642 bin TL azaltılmalıdır.

h. 2015 yılı için aktif çıtısı değişmemelidir. Kredi ve alacaklar çıktısı 18.092.056 bin TL arttırılmalıdır. Girdiler açısından bakıldığında çalışan sayısı 187, şube sayısı 290 ve mevduat kalemi 4.505.081 bin TL azaltılmalıdır.

i. 2016 yılı için Ziraatbank tam etkinlik düzeyi olan 1'e ulaştığı için girdi ve çıktı düzeylerinde herhangi bir değişiklik yapılmamalıdır.

j. 2017 yılı için Ziraatbank tam etkinlik düzeyi olan 1'e ulaştığı için girdi ve çıktı düzeylerinde herhangi bir değişiklik yapılmamalıdır.

Halkbank'ın 2008-2017 dönemindeki etkinlik göstergeleri ve etkin olan sinıra ulaşabilmesi kapsamında referans alması gerekli hedef rakamları ve oranları gösteren değerler Tablo 8' de yer almaktadır. Halk bankası 2013, 2016 ve 2017 yıllarında kullanılan girdi ve çıktıların analizi sonrasında tam etkinlik skoru olan 1'e ulaşmıştır.

Tablo 8. Halk Bankası VZA Sonuçları

\begin{tabular}{|c|c|c|c|c|c|c|c|}
\hline Y11 & Etkinlik Skoru & & Değişkenler & Gerçekleşen & Hedef & Fark & Referans \\
\hline \multirow{5}{*}{2008} & \multirow{5}{*}{0,902} & \multirow{2}{*}{ Çıktılar } & Kredi ve Alacaklar & 25.836 .298 & 29.860 .859 & 4.024 .555 & Vakıfbank \\
\hline & & & Aktif & 51.095 .895 & 51.095 .895 & - & - \\
\hline & & \multirow{3}{*}{ Girdiler } & Çalışan sayısı & 12.467 & 9365 & -3102 & Vakıfbank \\
\hline & & & Şube Sayısı & 622 & 514 & -108 & Vakıfbank \\
\hline & & & Mevduat & 40.271 .114 & 36.339 .659 & -3.931 .455 & Vakıfbank \\
\hline \multirow{5}{*}{2009} & \multirow{5}{*}{0,954} & \multirow{2}{*}{ Çıktılar } & Kredi ve Alacaklar & 32.458 .071 & 32.458 .071 & - & - \\
\hline & & & Aktif & 60.650 .086 & 60.834 .392 & 184.306 & Vakıfbank \\
\hline & & \multirow{3}{*}{ Girdiler } & Çalışan sayısı & 12.505 & 9.532 & -2.973 & Vakıfbank \\
\hline & & & Şube Sayısı & 669 & 511 & -158 & Vakıfbank \\
\hline & & & Mevduat & 43.949 .703 & 41.920 .668 & -2.029 .035 & Vakıfbank \\
\hline \multirow{5}{*}{2010} & \multirow{5}{*}{0,886} & \multirow{2}{*}{ Çıktılar } & Kredi ve Alacaklar & 44.296 .487 & 44.296 .487 & - & - \\
\hline & & & Aktif & 72.492 .385 & 73.030 .951 & 88.566 & Vakıfbank \\
\hline & & \multirow{3}{*}{ Girdiler } & Çalışan sayısı & 13.450 & 10.937 & -2.513 & Vakıfbank \\
\hline & & & Şube Sayısı & 709 & 628 & -81 & Vakıfbank \\
\hline & & & Mevduat & 54.782 .014 & 47.101.001 & -7.681 .013 & Vakıfbank \\
\hline \multirow{5}{*}{2011} & & \multirow{2}{*}{ Çıktılar } & Kredi ve Alacaklar & 56.216 .404 & 58.555 .342 & 2.338 .938 & Vakıfbank \\
\hline & & & Aktif & 91.123 .660 & 91.123 .660 & - & - \\
\hline & 0,940 & \multirow{3}{*}{ Girdiler } & Çalışan sayısı & 13.643 & 12.487 & -1.156 & Vakıfbank \\
\hline & & & Şube Sayısı & 771 & 695 & -76 & Vakıfbank \\
\hline & & & Mevduat & 66.246 .934 & 62.264 .257 & -3.982 .677 & Vakıfbank \\
\hline \multirow{2}{*}{2012} & \multirow{2}{*}{0,938} & \multirow{2}{*}{ Çıktılar } & Kredi ve Alacaklar & 65.893 .838 & 70.544 .448 & 4.650 .610 & Vakıfbank \\
\hline & & & Aktif & 108.281 .636 & 108.281 .636 & - & - \\
\hline
\end{tabular}


Türk Bankacılık Sisteminde Kamusal Sermayeli Bankaların Karşılaştırmalı Etkinlik Analizi: 2008-2017 Dönemi Değerlendirmesi

\begin{tabular}{|c|c|c|c|c|c|c|c|}
\hline Y11 & Etkinlik Skoru & & Değişkenler & Gerçekleşen & Hedef & Fark & Referans \\
\hline & & & Çalışan sayısı & 14.971 & 13.939 & -1.032 & Vakıfbank \\
\hline & & Girdiler & Şube Sayısı & 821 & 770 & -51 & Vakıfbank \\
\hline & & & Mevduat & 79.973 .901 & 69.622 .173 & -10.351 .728 & Vakifbank \\
\hline \multirow{5}{*}{2013} & \multirow{5}{*}{1.000} & \multirow{2}{*}{ Çıktılar } & Kredi ve Alacaklar & 84.848 .290 & 84.848 .290 & - & - \\
\hline & & & Aktif & 139.943 .507 & 139.943 .507 & - & - \\
\hline & & \multirow{3}{*}{ Girdiler } & Çalışan sayısı & 14.798 & 14.798 & - & - \\
\hline & & & Şube Sayısı & 877 & 877 & - & - \\
\hline & & & Mevduat & 100.756 .197 & 100.756 .197 & - & - \\
\hline \multirow{5}{*}{2014} & \multirow{5}{*}{0,975} & \multirow{2}{*}{ Çıktılar } & Kredi ve Alacaklar & 101.766 .924 & 102.736 .187 & 969.263 & Vakifbank \\
\hline & & & Aktif & 155.423 .019 & 155.423 .019 & - & - \\
\hline & & \multirow{3}{*}{ Girdiler } & Çalışan sayısı & 17.314 & 14.656 & -2.658 & Vakifbank \\
\hline & & & Şube Sayısı & 900 & 877 & -23 & Vakifbank \\
\hline & & & Mevduat & 103.708 .354 & 90.136 .202 & -13.572 .152 & Vakıfbank \\
\hline \multirow{5}{*}{2015} & \multirow{5}{*}{0,995} & \multirow{2}{*}{ Çıktılar } & Kredi ve Alacaklar & 126.744 .977 & 127.016 .271 & 271.294 & Vakıfbank \\
\hline & & & Aktif & 187.729 .350 & 187.729 .350 & - & - \\
\hline & & \multirow{3}{*}{ Girdiler } & Çalışan sayısı & 17.104 & 15.812 & -1.292 & Vakıfbank \\
\hline & & & Şube Sayısı & 949 & 944 & -5 & Vakıfbank \\
\hline & & & Mevduat & 122.145 .965 & 112.795 .901 & -9.350 .064 & Vakıfbank \\
\hline \multirow{5}{*}{2016} & \multirow{5}{*}{1.000} & \multirow{2}{*}{ Çıktılar } & Kredi ve Alacaklar & 158.354 .333 & 158.354 .333 & - & - \\
\hline & & & Aktif & 231.440 .818 & 231.440 .818 & - & - \\
\hline & & \multirow{3}{*}{ Girdiler } & Çalışan sayısı & 16.956 & 16.956 & - & - \\
\hline & & & Şube Sayısı & 964 & 964 & - & - \\
\hline & & & Mevduat & 150.262 .839 & 150.262 .839 & - & - \\
\hline \multirow{5}{*}{2017} & \multirow{5}{*}{1.000} & \multirow{2}{*}{ Çıktılar } & Kredi ve Alacaklar & 203.464 .477 & 203.464 .477 & - & - \\
\hline & & & Aktif & 305.350 .648 & 305.350 .648 & - & - \\
\hline & & \multirow{3}{*}{ Girdiler } & Çalışan sayısı & 17.851 & 17.851 & - & - \\
\hline & & & Şube Sayısı & 969 & 969 & - & - \\
\hline & & & Mevduat & 193.227.069 & 193.227.069 & - & - \\
\hline
\end{tabular}

Halkbank'ın veri zarflama analizi sonuçlarına göre etkin olmadığı dönemlerde etkinlik sınırına doğru yönelerek tam etkin olabilmesi için girdi ve çıtı kalemlerine yönelik yapması gerekli iyileştirmeler yıllar bazında aşağıda verilmiştir:

a. 2008 yılı için Aktif çıktısı değişmemelidir. Kredi ve alacaklar çıtısı 4.024 .555 bin TL arttırılmalıdır. Girdiler açısından bakıldığında ise çalışan sayısı 3.102, şube sayısı 108 ve mevduat kalemi 3.931.455 bin TL azaltılmalıdır.

b. 2009 yılı için kredi ve alacaklar çıktısı değişmemelidir. Aktif çıktısı 184.306 bin TL arttırılmalıdır. Girdiler açısından bakıldığında ise çalışan sayısı 2.973, şube sayısı 158 ve mevduat kalemi 2.029.035 bin TL azaltılmalıdır.

c. 2010 yılı için kredi ve alacaklar çıtısı değişmemelidir. Aktif çıtısı 88.566 bin TL arttırılmalıdır. Girdiler açısından bakıldığında ise çalışan sayısı 2.513, şube sayısı 81 ve mevduat kalemi 2.338.938 bin TL azaltılmalıdır.

d. 2011 yılı için aktif çıktısı değişmemelidir. Kredi ve alacaklar çıtısı 2.338.938 bin TL arttırılmalıdır. Girdiler açısından bakıldığında ise çalışan sayısı 1.156, şube sayısı 76 ve mevduat kalemi 3.982.677 bin TL azaltılmalıdır. 
e. 2012 yılı için aktif çıktısı değişmemelidir. Kredi ve alacaklar çıtısı 4.650 .610 bin TL arttırılmalıdır. Girdiler açısından bakıldığında ise çalışan sayısı 1.032, şube sayısı 51 ve mevduat kalemi 10.351.728 bin TL azaltılmalıdır.

f. 2013 yılı için Halkbank tam etkinlik düzeyi olan 1'e ulaştığı için girdi ve çıktı düzeylerinde herhangi bir değişiklik yapılmamalıdır.

g. 2014 yılı için aktif çıtısı değişmemelidir. Kredi ve alacaklar çıktısı 969.263 bin TL arttırılmalıdır. Girdiler açısından bakıldığında ise çalışan sayısı 2.658, şube sayısı 23 ve mevduat kalemi 13.572.152 bin TL azaltılmalıdır.

h. 2015 yılı için aktif çıktısı değişmemelidir. Kredi ve alacaklar çıktısı 271.294 bin TL arttırılmalıdır. Girdiler açısından bakıldı̆̆ında ise çalışan sayısı 1.292, şube sayısı 5 ve mevduat kalemi 9.350.064 bin TL azaltılmalıdır.

i. 2016 yılı için Halkbank tam etkinlik düzeyi olan 1'e ulaştığı için girdi ve çıktı düzeylerinde herhangi bir değişiklik yapılmamalıdır.

j. 2017 yılı için Halkbank tam etkinlik düzeyi olan 1'e ulaştığı için girdi ve çıktı düzeylerinde herhangi bir değişiklik yapılmamalıdır.

\section{Sonuç ve Öneriler}

2001 krizi öncesi dönemde Türk bankacılık sektörü ve özellikle kamusal sermayeli bankalar etkin yönetilmeyen, verimlilikten uzak, sürekli zarar açklayan bir görünümdeyken, 2001 krizi sonrasında özellikle kamusal sermayeli bankalar bilançosunu ve diğer mali verilerini düzelten, etkin yönetim sistemleri ile hizmet anlayışını yeniden şekillendiren bir kamu bankacilığına dönüşmüştür.

Çalışmadaki veriler incelendiğinde bu çerçevede, gerek personel ve şube sayısı gibi büyüklükleri, gerekse mevduat, kredi gibi bilanço kalemleri açısından kamusal sermayeli bankaların göstergeleri genel itibariyle pozitif bir eğilim ortaya koymaktadır. Bu kapsamda kamusal sermayeli Ziraatbank, Halkbank ve Vakıfbank'ın verileri, diğer sermaye grupları ile karşılaştırıldığında güçlü rekabet edebilme gücüne sahip olup, sektörde önemli bir büyüklüğe ulaşmışlardır.

Çalışmada veri zarflama analizi ile Ziraatbank, Halkbank ve Vakıfbank 2008-2017 arası dönemde karşılaştırmalı etkinlik analizine tabi tutulmuştur. Kullanılan girdi ve çıtıların analizi sonucunda Vakıfbank diğer iki bankaya göre daha etkin bulunmuştur. Bu kapsamda Ziraatbank ve Halkbank'ın daha etkin hale gelmesi için kullanılan girdi ve çıktı değerlerinde gerçekleştirmesi gereken düzeltmeler mevcuttur. Ziraatbank ve Halkbank'ın yapılan analiz sonuçlarına göre güncel ekonomik koşulları veri kabul edilerek, gelecek vizyonlarını hayata geçirirken tam etkinlik düzeyine ulaşmak için politikalarına yönelik aşağıdaki hususları göz önünde bulundurmalıdırlar:

a. Aktif pasif yapısı göz önünde bulundurarak kredi-mevduat dengesinde daha hassas davranmalıdır, 
b. Günümüzde banka büyüklükleri bankaların aktif büyüklüğü ile ölçülmektedir. Dolayısıyla aktif kalemi içerisinde önemli bir yeri olan krediler kaleminin arttırılması kamusal sermayeli bankaları diğer bankaların önüne taşıyacaktır,

c. Krediler kaleminin arttırılması aşamasında kredilendirme ilkeleri göz ardı edilmemelidir. Nitekim bir yandan kredi kalemleri arttırılırken, takipteki kredi rakamlarının artmaması bankalar açısından önemli olan diğer bir husustur,

d. Kredilendirmede dikkati olunması, Basel II kriterleri gibi uluslararası bankacılık kriterlerine uyumu beraberinde getirecektir. Dolayısıyla takipteki kredi rakamının azaltılması ile kamusal sermayeli bankaların Basel II kriterleri kapsamındaki kredi riski ile ilgili süreçleri daha sağlam ilerleyecektir,

e. Kredilerin ekonomik faaliyeti canlandıran yönü dikkate alındığında kamusal sermayeli bankaların sağlam kredi kalemindeki artışla ülkenin refahına önemli katkı sunulacaktır,

f. Bankaların aktifleri arasında kredilerin önemi nasıl büyükse, pasif yapısı içinde de en önemli kalemlerden biri mevduat kalemidir. Bu nedenle kredi devamlılığının sağlanması için mevduat kaleminin sürekliliği de önemlidir,

g. Kamusal sermayeli bankaların şubeleşme ağları diğer sermaye gruplarına ait bankalara göre günümüzde daha yaygındır. Her ne kadar küçük yerleşim birimlerine bile hizmet götürme anlayışı ile hareket edilse de, kamusal sermayeli bile olsalar bankalar birer ticari işletme olarak öncelikle kar elde edebilme mantığ 1 ile hareket etmelidir.

h. Şubeleşme ile birlikte personel istihdamında da aynı odak noktası ile hareket edilmelidir. Fazla personel istihdamından ziyade, mevduat-kredi döngüsüne destek sağlayacak, günümüz bankacılık sistemine ayak uyduracak nitelikli personel istihdamı hedeflenmelidir.

\section{Kaynakça}

Alam, Nafıs (2013). "Impact of Banking Regulation on Risk and Efficiency in Islamic Banking”, Journal of Financial Reporting and Accounting, Vol: 11, No: 1,ss.29-50.

Altan, Mitra Salimi. Türk Sigortacılık Sektöründe Etkinlik: Veri Zarflama Analizi Yöntemi ile Bir Uygulama (2010). Gazi Üniversitesi İktisadi ve İdari Bilimler Fakültesi Dergisi, Cilt: 12, No: 1 , ss.1-20.

Ayrıçay, Y., Özçalıcı, M. (2015). 1997-2012 Yılları Arasında Türkiye' de Veri Zarflama Analizi İle İlgili Yayınlanan Akademik Çalışmalar. Kahramanmaraş Sütçü İmam Üniversitesi İktisadi ve İdari Bilimler Fakültesi Dergisi, 4(1), 246-279.

Babacan, Adem, Kısakürek, M. Mustafa ve Özcan, Selami (2009). “IMKKB'ye Kote Edilmiş Firmaların Vza Yöntemi İle Performans Ölçümleri”, Dumlupınar Üniversitesi Sosyal Bilimler Dergisi, Cilt: 24, ss.23-37.

Banker RD, A Charnes and WW Cooper (1984). "Some Models for Estimating Technical and Scale Inefficiencies in Data Envelopment Analysis", Management Science, Vol: 30, No: 9, 1984, ss.1078-1092. 
Behdioğlu, Sema ve Özcan, Gözde (2009). “Veri Zarflama Analizi ve Bankacılık Sektöründe Bir Uygulama", Süleyman Demirel Üniversitesi İ̈BF Dergisi, Cilt: 14, Sayı: 3, ss.301-326.

Budak, Hüseyin (2011). Veri Zarflama Analizi ve Türk Bankacılık Sektöründe Uygulaması, Marmara Üniversitesi Fen Bilimleri Dergisi, Cilt:23, No:3, ss.95-110.

Charnes Abraham, Cooper, William W., Rhodes, Edwardo (1978). "Measuring the Efficiency of Decision Making Units", European Journal of Operational Research, Vol. 2, 1978.

Emiral, Fatih (2018). “Türk Bankacılık Sisteminde Etkinlik Analizi (Veri Zarflama Analizi Uygulamas1)", Deloitte

Dergisi. http://www.denetimnet.net/UserFiles/Documents/24 6.pdf, (10.05.2018).

Farrell M.J. (1957). "The Measurement of Productive Efficiency", Journal of Royal Statistical Society, Vol: 120, 1957, ss. 253-290.

Gülcü, Aslan, Tutar, Hasan, Yeşilyurt Cavit (2005). Sağlık Sektöründe Veri Zarflama Analizi Yöntemi ile Göreceli Verimlilik Analizi, Seçkin Yayıncılık, 2005.

İnan, E.Alpan (2000). “Banka Etkinliğinin Ölçülmesi ve Düşük Enflasyon Sürecinde Bankacılıkta Etkinlik", Bankacılar Dergisi, Sayı: 34, 2000, ss.82-97.

Johnes, Jill, Izzeldin, Marwan ve Pappas, Vasileios (2014). “A Comparison of Performance of Islamic and Conventional Banks 2004-2009", Journal of Economic Behavior \& Organization, Vol: 103, 2014, ss.93-107.

Kaygısız, Z., Girginer, N.,(2011). Maliyet etkinlik analizi: Türkiye'deki büyükşehir belediyelerinde uygulama. Eskişehir Osmangazi Üniversitesi İ̈BF Dergisi, 6(2), 309-342.

Kök Dündar ve Ay, O.Evren (2013). “2008 Küresel Finansal Krizinin Türk Bankacılık Sektörü Etkinlik Düzeylerine Yansıması Üzerine Bir Arastırma: 2007-2009”, Uluslararası Iktisadi ve Idari Incelemeler Dergisi, Y11:5 Sayı:10, 2013, ss.155-170.

Kutlar, A., Kartal, M.,(2004). Cumhuriyet Üniversitesinin verimlilik analizi: Fakülteler düzeyinde veri zarflama yöntemiyle bir uygulama. Kocaeli Üniversitesi Sosyal Bilimler Enstitüsü Dergisi, 8(2), 49-79.

Mohammed Khaled I. Bader, Mohamad, Shamsher; Ariff, Mohamed; Shah, Taufiq Hassan (2008). "Cost, Revenue, and Profit Efficiency of Islamic Versus Conventional Banks: Internatıonal Evidence Using Data Envelopment Analysıs", Islamic Economic Studies, Vol: 15, No: 2, January, 2008.

Özgür, E.(2008). Katılım bankalarının finansal etkinliği. Afyon Kocatepe Üniversitesi, İ̈BF Dergisi, 10(1), 159-175.

Repkova, Iveta. "Efficiency of the Czech banking sector employing the DEA window analysis approach", Procedia Economics and Finance, Vol: 12, 2014, ss.587-596.

Savaş, Filiz (2015). “Veri Zarflama Analizi”, Çok Kriterli Karar Verme Yöntemleri, (Ed: Bahadır Fatih Yıldırım, Emrah Önder), Dora Yayınevi, İkinci Baskı, Bursa, 2015.

Sufian, Fadzlan (2007). "The Efficiency Of Islamic Banking Industry: A Non-Parametric Analysıs With Non-Discretionary Input Variable", Islamic Economic Studies, Vol: 14, No: 1 \& 2, Aug. 2006 \& Jan. 2007. 
Sufian, Fadzlan ve Kamarudin, Fakarudin(2014). "Efficiency and Returns to Scale in the Bangladesh Banking Sector: Empirical Evidence from the Slack-Based DEA Method", Inzinerine Ekonomika-Engineering Economics, Vol: 25, No:5, 2014, ss.549-557.

Tarkoçin, Coşkun ve Gençer, Murat (2010). “Farklı Girdi ve Çıktı Yaklaşımlarının Veri Zarflama Analizi Etkinlik Sonuçlarına Etkisi ve Türk Ticari Bankaları Uygulaması", Bankacılar Dergisi, Sayı: 72, 2010, ss.19-32.

Taylor, William M., Thompson, Russell G., Thrall, Robert M., Dharmapala, P.S. (1997). “DEA/AR Efficiency and Profitability of Mexican Banks A Total income Model”, European Journal of Operational Research, Vol: 98, 1997, ss.346-363.

Temür, Y.,(2009). İllerin gelişmişlik derecelerine göre hastanelerin etkinlik analizi. Uludağ Üniversitesi İ̈BF Dergisi, 29(2), 1-22.

Thanh Pham Thien Nguyen, Roca, Eduardo ve Sharma, Pharmendra (2014). “How Efficient is the Banking System of Asia's Next Economic Dragon? Evidence from Rolling DEA Windows", Applied Economics, Vol: 46, No: 22, 2014, ss 2665-2684.

Titko, Jelena, Stankevičienè. Jelena ve Lāce Natalja (2014). “Measuring bank efficiency: DEA application, Technological and Economic Development of Economy, Vol: 20, No:4, 2014, ss.739-757.

Tsolas, Ioannis E. ve Charles, Vincent (2015). “Incorporating risk into bank efficiency: A satisficing DEA approach to assess the Greek banking crisis", Expert Systems with Applications, Vol. 42, 2015, ss.3491-3500.

Türkiye Bankalar Birliği, İstatistiki Raporlar, www.tbb.org.tr.

Yetiz, Filiz (2016). Bankacılığın Doğuşu ve Türk Bankacılık Sistemi, Niğde Üniversitesi İktisadi ve İdari Bilimler Fakültesi Dergisi, Nisan 2016; 9(2)

Wolters, Mark Edward, Do Couto, Eduardo Barbosa ve Felício, José Augusto (2014). "The Effects of the Global Financial Crisis On Brazilian Banking Efficiency", Innovar, Vol: 24, No: 53, 2014, ss.23-39.

Zainal, Noor Saliza and İsmail, Mahadzir (2012). “Islamıc Bankıng Effıcıency: A Dea Approach, 3rd International Conference on Business and Economic Research, Proceeding, 12 - 13 March 2012, Bandung, Indonesia. 